\title{
Comparison of two models of hospital rehabilitation in patients after coronary artery bypass grafting
}

\author{
Daniel Karaszewski \\ Klinika Kardiochirurgii, I Katedra i Klinika Kardiologii, Warszawski Uniwersytet Medyczny \\ Kardiochirurgia i Torakochirurgia Polska 2014; 11 (1): 86-89
}

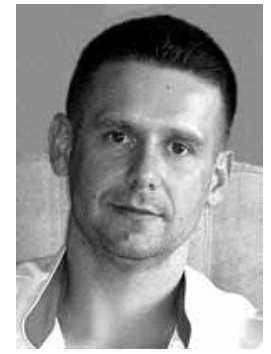

\begin{abstract}
Introduction: Taking into consideration the rise in ischemic heart disease and the increasing number of performed cardiac surgery procedures, attempts have been made to prepare an optimal rehabilitation program enabling the effective improvement of patient condition in the shortest possible time-frame that would be of most benefit for the patients [1, 2].

Aim of the study was to compare the therapeutic efficacy of two rehabilitation models ( - a modified model, and II - the standard cardiac rehabilitation model of the Polish Cardiac Society) during early hospitalization in patients after coronary artery bypass graft surgery (CABG).

Material and methods: Between December 2011 and April 2012, the study examined 42 men (aged 48-76) who underwent myocardial revascularization at the Clinic of Cardiac Surgery of the $1^{\text {st }}$ Chair and Clinic of Cardiology of the Medical University of Warsaw. The patients were randomly assigned to one of two groups: A (model I) and B (model II), with 21 patients in each group. The qualification process for the procedures was planned, the postoperative course was uneventful, and the patients were discharged from the ward as normal (between the $7^{\text {th }}$ and $10^{\text {th }}$ postoperative day). In order to compare the two employed models, a 6-minute walk test was conducted during the $7^{\text {th }}$ day of postoperative rehabilitation.

Results: Differences between the study groups were revealed with regard to heart rate values (group $A$ - mean heart rate before the test: $78 \mathrm{bpm}$, after the test: $82 \mathrm{bpm}$; group B - mean heart rate before the test: $82 \mathrm{bpm}$, after the test: $87 \mathrm{bpm}$ ) and perceived exertion (group A - mean exertion level: 0.5 points, group B - mean exertion level: 0.7 points).

Conclusions: The modified rehabilitation model exerts a better therapeutic effect on the patients than the standard one. The introduced modifications are safe, as the applied physical exertion is well tolerated by patients.
\end{abstract}

Key words: rehabilitation in cardiac surgery, coronary artery bypass grafting, physical training.

\section{Streszczenie}

Wstęp: Ze względu na rozwój choroby niedokrwiennej serca oraz wzrost liczby wykonywanych zabiegów kardiochirurgicznych dąży się do opracowania optymalnego programu rehabilitacyjnego, który pozwoliłby efektywnie usprawniać chorych w możliwie najkrótszym i korzystnym dla pacjenta czasie [1, 2]. Celem pracy było porównanie pod względem efektywności terapeutycznej dwóch modeli rehabilitacyjnych: I - modelu zmodyfikowanego, oraz II - modelu standardowego rehabilitacji kardiologicznej Polskiego Towarzystwa Kardiologicznego, w okresie wczesnym szpitalnym u pacjentów po przebytym wszczepieniu pomostów aortalno-wieńcowych.

Materiat i metody: W okresie grudzień 2011 r. - kwiecień 2012 r. przebadano 42 mężczyzn (48-76 lat), których poddano zabiegowi rewaskularyzacji mięśnia sercowego w Klinice Kardiochirurgii I Katedry i Kliniki Kardiologii Warszawskiego Uniwersytetu Medycznego. Pacjentów przydzielono losowo do dwóch grup: A (I model) i B (II model), po 21 osób w każdej. Badanych charakteryzowała planowa kwalifikacja do zabiegu, niepowikłany przebieg pooperacyjny, a także standardowe wypisanie z oddziału szpitalnego między 7. a 10. dobą pooperacyjną. W celu porównania zastosowanych modeli w 7. dobie rehabilitacji pooperacyjnej przeprowadzono test marszu 6-minutowego.

Wyniki: Wykazano różnice pomiędzy badanymi grupami w zakresie wartości tętna (grupa A - średnie tętno przed testem $78 / \mathrm{min}$ i po teście $82 / \mathrm{min}$, grupa B - średnie tętno przed testem $82 / \mathrm{min}$ i po teście $87 / \mathrm{min}$ ) oraz odczuwalnego zmęczenia (grupa A - średni poziom zmęczenia 0,5 pkt, grupa B - średni poziom zmęczenia 0,7 pkt).

Wnioski: Zmodyfikowany model usprawniania w porównaniu z modelem standardowym wpływa korzystniej na efekt terapeutyczny. Wprowadzone modyfikacje są bezpieczne, gdyż zastosowany wysiłek fizyczny jest dobrze tolerowany przez pacjentów.

Słowa kluczowe: rehabilitacja w kardiochirurgii, pomostowanie aortalno-wieńcowe, trening fizyczny. 


\section{Introduction}

The dynamic civilizational progress, the intensity of everyday life, as well as the harmful eating habits and lifestyle of modern populations result, in an increasingly calculable manner, in the rise of cardiovascular diseases in general and ischemic heart disease in particular [3].

In the field of cardiac surgery, the number of performed procedures is growing. This necessitates the development of new post-cardiac surgery rehabilitation methods. Taking into consideration the global tendencies, economic capabilities, and conducted studies, attempts are being made to devise an optimal rehabilitation program that would enable the effective improvement of patient condition in the shortest possible time-frame that would be of most benefit for the patients. A properly selected model of rehabilitation after cardiac surgery should result in the improvement of physical capacity and exercise tolerance $[2,4]$.

\section{Aim of the study}

The aim of this study was to compare the therapeutic efficacy of two rehabilitation models ( $1-$ a modified model, and II - the standard cardiac rehabilitation model of the Polish Cardiac Society) during early hospitalization in patients after coronary artery bypass graft surgery (CABG).

\section{Material and methods}

The study examined 42 men (aged 48-76) diagnosed with ischemic heart disease who underwent myocardial revascularization between December 2011 and April 2012 at the Clinic of Cardiac Surgery of the $1^{\text {st }}$ Chair and Clinic of Cardiology of the Medical University of Warsaw. The patients were randomly assigned to one of two groups: A (rehabilitation model I) and B (rehabilitation model II), with 21 patients in each group. Patient selection was conducted according to the following inclusion criteria: the qualification process for the procedures was planned, the postoperative course was uneventful, and the patients were discharged from the ward as normal (between the $7^{\text {th }}$ and the $10^{\text {th }}$ postoperative day).

Both models (model I and model II) featured the following elements:

- breathing exercises (abdominal breathing, upper and lower thoracic breathing) with and without resistance,

- bronchial hygiene procedures,

- active exercises for the upper and lower extremities,

- general fitness exercises,

- walking along the corridor and walking the stairs,

- upper torso massage.

The differences between the models were related to the duration and intensity of the exercises, the employed loads, and the regimen of walking the stairs and walking along the corridor.

Model I:

- exercise duration - 10 to 30 minutes depending on the postoperative day (10-15 minutes on days 1-2, 15-20 minutes on days 3-5, 20-30 minutes on days 6-10),
- frequency - twice per day,

- intensity and loads - intervals (with regard to walking along the corridor and walking the stairs),

- walking along the corridor on the $3^{\text {rd }}-4^{\text {th }}$ postoperative day,

- walking the stairs (up to the $3^{\text {rd }}$ floor) on the $4^{\text {th }}-5^{\text {th }}$ postoperative day.

Model II:

- exercise duration - 5 to 20 minutes depending on the postoperative day (5-10 minutes on days 1-2, 10-15 minutes on days 3-5, 15-20 minutes on days 6-10),

- frequency - twice per day,

- intensity and loads - constant,

- walking along the corridor on the $6^{\text {th }}-10^{\text {th }}$ postoperative day,

- walking the stairs (up to the $2^{\text {nd }}$ floor) on the $6^{\text {th }}-10^{\text {th }}$ postoperative day [5].

The studied patients from both groups ( - model I, and $\mathrm{B}$ - model II) underwent preoperative breathing rehabilitation at the cardiac surgery ward and received general instructions concerning their postoperative rehabilitation. The duration of this period varied due to the different lengths of each patient's preoperative stay at the ward, which ranged from 1 to 3 days. Exercise frequency was the same for both groups (twice per day). The postoperative rehabilitation of the studied patients from both groups began on the $1^{\text {st }}$ postoperative day and was continued until the last day of their stay at the cardiac surgery ward.

In order to compare the two employed models (model I - group A, model II - group B), a 6-minute walk test was conducted for each patient during the $7^{\text {th }}$ day of postoperative rehabilitation.

The 6-minute walk test was conducted on one of the hospital corridors. The test was preceded by plotting out a $50 \mathrm{~m}$ route with precisely marked turning points. In order to facilitate taking measurements, $2 \mathrm{~m}$ stretches were also marked throughout the length of the set distance. Before, during, and after the test, the following protocol, similar to those used in the case of other cardiac stress tests, was used: short patient interviews were conducted; the test took place at least 2 hours after the last meal and the administration of medication; the patients received instructions concerning the testing method (including the rule of adjusting their walking pace to the perceived exertion); the patients rested before the test; visual and verbal contact was maintained between each examined patient and the examiner. Immediately before the start of the test, each patient underwent measurement of heart rate, arterial pressure, and saturation while remaining in a sitting position. During the 6-minute walk test, each patient was informed about the passing time in one-minute intervals. Immediately after the walk test, each patient again underwent measurement of heart rate, arterial pressure, and saturation while remaining in a sitting position; their perceived exertion was scored according to the Borg scale (ranging from 1 to 10+), and their covered distance was noted [6]. 
For statistical analysis, the Wilcoxon signed-rank test, the Mann-Whitney $U$ test, and Spearman's rank-order correlation were used. A $p$ value of $<0.05$ was considered statistically significant.

\section{Results}

All the included patients completed the 6-minute walk test. The mean age of the participants was 64 years in group $A$ and 62 years in group $B$.

1. The values of arterial pressure before and after the test.

Before the test:

- group A - mean arterial pressure: 113/77 mm Hg; group B - mean arterial pressure: 116/78 mm Hg.

After the test:

- group A - mean arterial pressure: 115/77 mm Hg; group B - mean arterial pressure: 121/79 mm Hg.

The Wilcoxon signed-rank test demonstrated a statistically significant difference between the arterial pressure results obtained before and after the test in group B (systolic pressure: $p=0.007066$, diastolic pressure: $p=0.013833$ ).

The Mann-Whitney $U$ test did not reveal statistical significance.

2. The values of heart rate observed before and after the test (Fig. 1).

Before the test:

- group A - mean heart rate: 78 bpm; group B - mean heart rate: $82 \mathrm{bpm}$.

After the test:

- group A - mean heart rate: 80 bpm; group B - mean heart rate: $87 \mathrm{bpm}$.

The Wilcoxon signed-rank test demonstrated a statistically significant difference between the heart rate results obtained before and after the test in both groups (group A $-p=0.005234$, group $\mathrm{B}-p=0.000182$ ).

The Mann-Whitney $U$ test demonstrated statistically significant differences between group $A$ and group $B$ with regard to heart rate, both before and after the test (heart

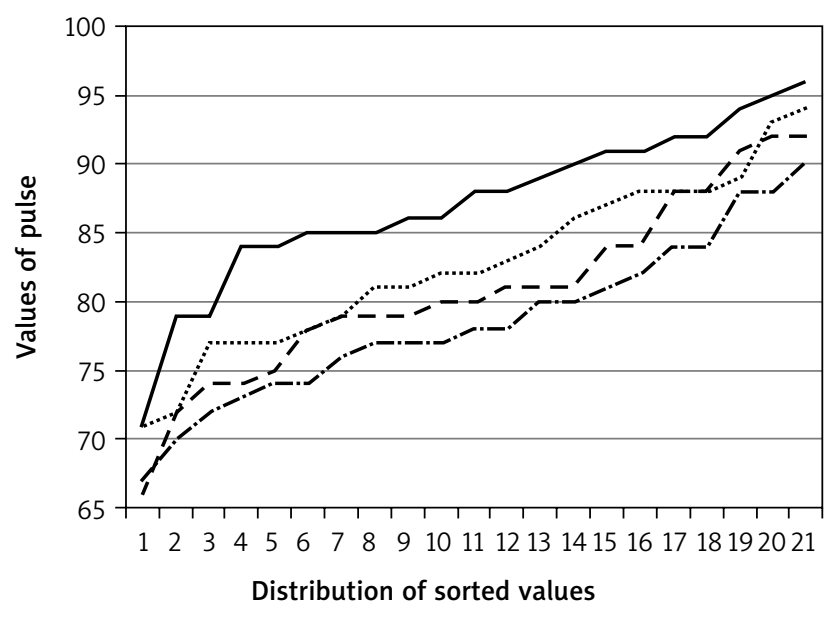

---Group A - Pulse before test _ - - Group A - Pulse after test ...... Group B - Pulse before test - Group B - Pulse after test

Fig. 1. Distribution of heart rate values before and after the test for groups $A$ and $B$ rate before the test: $p=0.043538$, heart rate after the test: $p=0.003725$ ).

3. Saturation values before and after the test.

Before the test:

- group A - mean saturation of $95 \mathrm{SpO}_{2}$; group $\mathrm{B}$ - mean saturation of $95 \mathrm{SpO}_{2}$.

After the test:

- group A - mean saturation of $97 \mathrm{SpO}_{2}$; group $\mathrm{B}$ - mean saturation of $97 \mathrm{SpO}_{2}$.

The Wilcoxon signed-rank test demonstrated statistically significant differences between the saturation results obtained before and after the test in both groups (group $A$ $-p=0.000271$, group $\mathrm{B}-p=0.000196)$.

The Mann-Whitney $U$ test did not reveal statistical significance.

4. Perceived exertion after the test according to the Borg scale (Fig. 2).

- Group A - average exertion score: 0.5 points; group B - average exertion score: 0.7 points.

The Mann-Whitney $U$ test did not reveal a statistically significant difference between the groups with regard to perceived exertion. It was, however, a borderline result $p=0.528$.

5. Distance covered during the test.

- Group A - average distance covered: $655 \mathrm{~m}$; group B average distance covered: $635 \mathrm{~m}$.

The Mann-Whitney $U$ test did not reveal statistical significance.

In group A, Spearman's rank-order correlation revealed statistically significant relationships between patient age and the distance covered during the test $(r=-0.81)$, as well as between post-test heart rate and post-test perceived exertion according to the Borg scale $(r=0.48)$. In group B, it demonstrated a statistically significant relationship between post-test heart rate and post-test perceived exertion according to the Borg scale $(r=0.57)$.

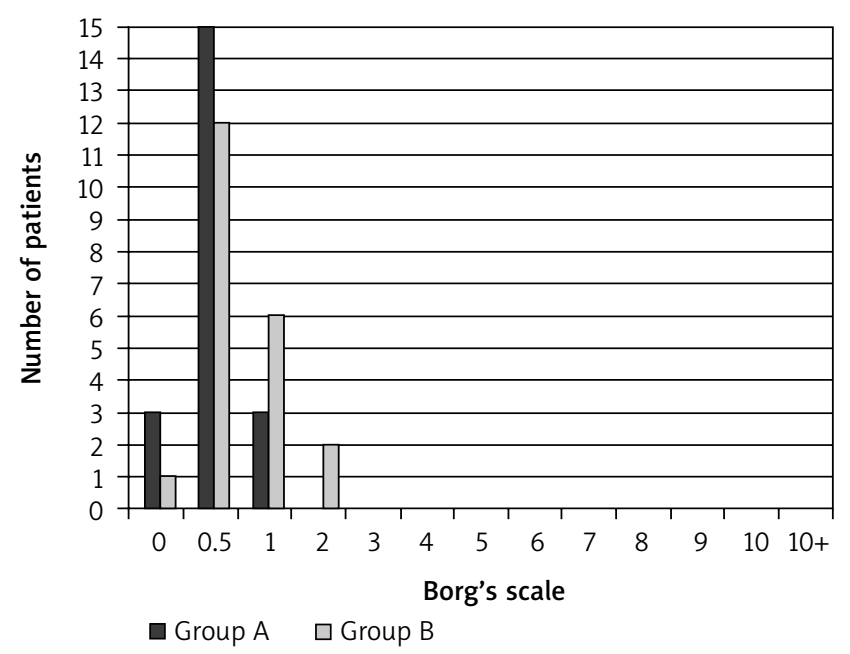

0 - unnoticeable, 0.5 - very, very small, 1 - very small, 2 - small, 3 - average, 4 - quite noticeable, 5, 6 - noticeable,

7, 8, 9 - very noticeable, 10 - very, very noticeable, $10+-$ maximum

Fig. 2. Perceived exertion after the test for groups A and B according to the Borg RPE Scale 


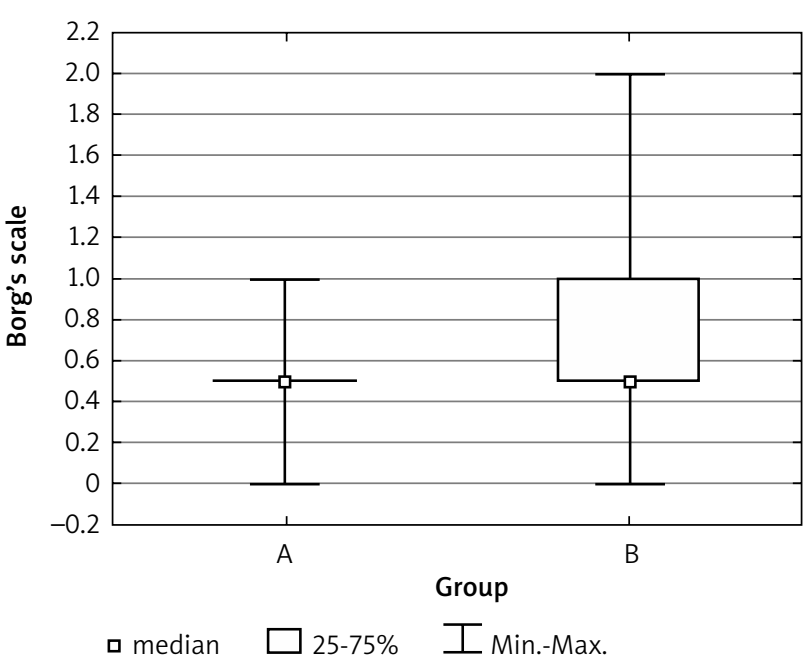

Fig. 3. Perceived exertion after the test for groups A and B according to the Borg RPE Scale

\section{Discussion}

The present study describes the period of the patients' hospital rehabilitation following myocardial revascularization, which constitutes one of the stages of the rehabilitation process (the hospital and post-hospital periods). It is difficult to expect these several days of exercise at the cardiac surgery ward to result in long-term effects in the form of accomplishing the primary objectives, such as lasting and significant improvement of exercise tolerance or sufficient growth of physical capacity $[7,8]$.

The presented work attempts to present a view based on widely applied studies. Its main objective was to compare the two described rehabilitation models and to demonstrate the point of modifying accepted rehabilitation standards in order to achieve measurable benefits for the patients.

The conducted 6-minute walk test revealed statistically significant differences in the values of heart rate before and after the test between the two groups. Both before and after the test, the heart rate values of group A patients were lower and closer to normal than was the case with group $B$. Significant differences between groups $A$ and $B$ were also noted with regard to perceived exertion according to the Borg scale (Fig. 3). Group A patients demonstrated better exercise tolerance, as indicated by their lower levels of perceived exertion in comparison to group B. Considering these results, the possibilities of their interpretation, and the size of the groups (42 patients in two equally sized groups), it appears worthwhile to continue the research on a larger number of patients in order to reveal or eliminate the differences between the two groups.

\section{Conclusions}

The proposed modified rehabilitation model exerts a more beneficial therapeutic effect in comparison to the standard rehabilitation model.

The introduced modifications, concerning increased exercise duration and intensity as well as different loads, are safe, as the applied physical exertion is well tolerated by patients.

\section{References}

1. Rudnicki S. Rehabilitacja w chorobach układu krążenia i po operacjach serca. In: Kwolka A (ed.). Rehabilitacja medyczna. Vol. 2. Urban \& Partner, Wrocław 2003; p. 309.

2. Kazimierska B, Smolis-Bąk E, Kowalik I, Dąbrowski R, Rudnicki S. Czy skrócenie czasu rehabilitacji u chorych po wszczepieniu pomostów aortalno-wieńcowych pozwoli na pełne i prawidłowe ich uruchomienie. Postępy Rehabilitacji 2000; 14: 71-72.

3. Majewicz A, Marcinowski JT. Epidemiology of cardiovascular diseases. Why in Poland there is such a low interest in existing prophylactic programs? Probl Hig Epidemiol 2008; 89: 322-325.

4. Borowicz-Bieńkowska S, Przywarska I, Dylewicz P, Wilk M, Szczęśniak $t$, Rychlewski T. Wpływ różnych form treningu wytrzymałościowego na efekty rehabilitacji chorych po operacjach pomostowania aortalno-wieńcowego. Postępy Rehabilitacji 2002; 16: 27.

5. Członkowie Komisji ds. Opracowania Standardów Rehabilitacji Kardiologicznej. Specyficzne problemy rehabilitacji kardiologicznej w różnych sytuacjach klinicznych. Folia Cardiologica 2004; 11 (Suppl A): A32-A41.

6. ATS Committee on Proficiency Standards for Clinical Pulmonary Function Laboratories. ATS statement: guidelines for the six-minute walk test. Am J Respir Crit Care Med 2002; 166: 111-117.

7. Kustrzycki W, Dąbrowska G. Rehabilitacja w kardiochirurgii. In: Woźniewski M, Kołodziej J (eds.). Rehabilitacja w chirurgii. Wydawnictwo Lekarskie PZWL, Warszawa 2006; pp. 109-132.

8. Piotrowicz R, Wolszakiewicz J. Rehabilitacja kardiologiczna pacjentów z chorobą wieńcową. Kardiologia dla lekarzy rodzinnych. Mediapress Medical Update 2003; 6: 3-9. 